\title{
HUBUNGAN ANTARA SIKAP TERHADAP BEBAN TUGAS DENGAN STRES AKADEMIK MAHASISWA FAKULTAS KEDOKTERAN
}

\author{
Irma Finurina Mustikawati ${ }^{1}$, Prima Maharani Putri ${ }^{1}$ \\ ${ }^{1}$ Fakultas Kedokteran Universitas Muhammadiyah Purwokerto
}

\begin{abstract}
ABSTRAK
Penelitian ini bertujuan untuk mengetahui hubungan antara sikap terhadap beban tugas dengan stres akademik mahasiswa fakultas kedokteran. Jenis penelitian yang dilakukan adalah correlational research (penelitian korelasional), karena penelitian ini ingin mengetahui sejauhmana hubungan variabel sikap terhadap beban tugas dengan stres akademik mahasiswa fakultas kedokteran. Penelitian ini dilakukan dengan metode kuisioner. Teknik pengambilan sampel dalam penelitian ini menggunakan probability sampling dengan jenis simple random sampling, didapatkan sampel sebanyak 149 mahasiswa. Dengan variabel dependen stres akademik. Sedangkan variabel independen penelitian ini adalah sikap terhadap beban tugas. Data yang diperoleh dianalisis menggunakan uji korelasi pearson menunjukkan hubungan yang signifikan antara stres akademik dengan sikap terhadap beban tugas pada mahasiswa Kedokteran dengan arah hubungan yang positif dan kekuatan hubungan kuat $(\mathrm{p}=0.000 ; \mathrm{r}=0.626)$.
\end{abstract}

Kata kunci: stres akademik, sikap terhadap beban tugas, mahasiswa

\begin{abstract}
This study aims to determine the relationship between attitudes towards the task burden with the academic stress of medical faculty students. The type of research conducted was correlational research, because this study wanted to find out how far the relationship of attitude variables to the task burden with the academic stress of medical faculty students. This research was conducted by questionnaire method. The sampling technique in this study uses probability sampling with the type of simple random sampling, obtained a sample of 149 students. With the dependent variable academic stress. While the independent variable of this study is the attitude towards the task burden. The data obtained were analyzed using Pearson correlation test showed a significant relationship between academic stress with the attitude towards the task burden on medical students with a positive relationship and strong relationship strength $(\mathrm{p}=0.000 ; \mathrm{r}=0.626)$.
\end{abstract}

Keywords: academic stress, attitudes towards workload, student

\section{PENDAHULUAN}

Mahasiswa sebagai aset negara dalam

mewujudkan sumber daya manusia yang berkulitas sangat dituntut dalam mengembangkan kemampuan dan ketrampilannya agar dapat bersing di era globalisasi. Terutama pada mahasiswa fakultas kedokteran sebagai pembelajar di perguruan tinggi harus mampu beradaptasi dengan baik dalam situasi belajar yang baru, sistem pembelajaran yang berbeda ketika berada di sekolah lanjutan atas, baik dari waktu, teknik pembelajarannya yang mandiri (student centered learning), praktikum, skill lab, tutorial, yang kesemuanya tercakup dalam sistem blok dimana dalam setiap semesternya terdiri dari tiga blok. Cara belajar yang baik tersebut dapat memungkinkan efisiensi dan efektivitas waktu dan tenaga dalam belajar. Kemampuan adaptasi pada mahasiswa fakultas 
kedokteran tersebut jika mengalami kegagalan maka akan mengakibatkan stres pada mahasiswa. ${ }^{1}$

Kegagalan dalam melakukan penyesuaian diri dari beberapa masalah tersebut dapat menimbulkan tekanan mental bagi mahasiswa yang bersangkutan. Moore menyatakan bahwa stres mahasiswa berbeda dalam hal stresor. Stresor mahasiswa dapat berupa keuangan, beban tugas, ujian dan masalah interaksi dengan temannya ${ }^{2}$.

Menurut Siswanto mahasiswa telah mengalami berbagai perubahan hidup terutama pada sistem belajarnya. Perubahan tersebut mengakibatkan mahasiswa mengalami tekanan ${ }^{3}$. Kekurangmampuan dalam melakukan penyesuaian diri dengan situasi dan tuntutan yang ada dapat menimbulkan tekanantekanan bagi remaja yang bersangkutan. Hal tersebut jika dibiarkan tanpa penyelesaian akan memengaruhi kesehatan mental yang bersangkutan. ${ }^{3}$

Pendapat tersebut didukung oleh Taylor et al bahwa beberapa jenis peristiwa lebih cenderung menimbulkan stres. Setiap peristiwa yang menuntut seseorang untuk menyesuaikan diri, membuat perubahan atau mengeluarkan sumber daya, berpotensi menimbulkan stres $^{4}$. Seseorang diakatan mengalami stres jika muncul gejala-gejala seperti gejala fisik, emosi, dan gejala perilaku ${ }^{5}$.

Seseorang yang mengalami stres mereka akan kehilangan motivasi untuk melakukan kegiatan sehariharinya sebagai akibat dari banyaknya stressor yang diterima. Menurut Rizvi kondisi tersebut dapat memicu mahasiswa melakukan prokrastinasi akademik dalam menyelesaikan tugas hingga menunda belajar untuk ujian ${ }^{2}$. Friedberg menambahkan akibat buruk dari stres adalah meningkatnya kelelahan hingga mengakibatkan ketidakmampuan, kondisi lelah mengakibatkan turunnya produktivitas dalam belajar maupun aktivitas pribadi $^{2}$.

Berhubungan dengan stres, ada beberapa faktor yang memengaruhi stres yang dialami mahasiswa fakultas kedokteran. Menurut Cooper salah satu kondisi itu adalah yang meliputi beban tugas yang berlebihan atau beban tugas yang kurang ${ }^{6}$. Mahasiswa fakultas kedokteran mengalami stres karena banyaknya tugas yang menuntut penyelesaiannya secara bersamaan, sehingga faktor yang akan diteliti pada penelitian ini adalah beban tugas yang diterima mahasiswa, dan bagaimana beban tugas tersebut ditanggapi sebagai sesuatu yang positif atau negatif baginya tergantung dari sikapnya dalam menghadapi beban tugas tersebut.

Respon mahasiswa tersebut terhadap beban tugasnya, merupakan gambaran dari sikap yang dimiliki. Sikap menurut Walgito merupakan organisasi pendapat, keyakinan seseorang mengenai objek atau situasi yang relatif ajeg, yang disertai adanya perasaan tertentu, dan memberikan dasar kepada orang tersebut untuk membuat respons atau berperilaku dalam cara tertentu yang dipilihnya ${ }^{7}$. Secord dan Backman 
menambahkan bahwa sikap adalah keteraturan tertentu dalam hal perasaan (afeksi), pemikiran (kognitif), dan predisposisi tindakan (konasi) seseorang terhadap suatu aspek di lingkungan sekitarnya ${ }^{8}$. Hal tersebut ditunjang dengan adanya struktur sikap yang terbagi dalam tiga komponen sikap yaitu: (1) Komponen kognitif merupakan representasi apa yang dipercayai oleh individu pemilik sikap, komponen kognitif berisi kepercayaan stereotype yang dimiliki individu mengenai sesuatu dapat disamarkan penanganan (opini) terutama apabila menyangkut masalah isu atau problem yang kontroversal. (2) Komponen afektif merupakan perasaan yang menyangkut aspek emosional. Aspek emosional inilah yang biasanya berakar paling dalam sebagai komponen sikap dan merupakan aspek yang paling bertahan terhadap pengaruh-pengaruh yang mungkin adalah mengubah sikap seseorang komponen afektif disamakan dengan perasaan yang dimiliki seseorang terhadap sesuatu. (3) Komponen konatif merupakan aspek kecenderungan berperilaku tertentu sesuai dengan sikap yang dimiliki oleh seseorang. Dan berisi tendensi atau kecenderungan untuk bertindak/ bereaksi terhadap sesuatu dengan cara-cara tertentu dan berkaitan dengan objek yang dihadapinya adalah logis untuk mengharapkan bahwa sikap seseorang adalah dicerminkan dalam bentuk tendensi perilaku ${ }^{8}$

Berdasarkan latar belakang diatas, peneliti tertarik untuk mengangkat topik mengenai hubungan antara sikap terhadap beban tugas dengan stres akademik mahasiswa fakultas kedokteran.

\section{METODE PENELITIAN}

Jenis penelitian yang dilakukan adalah correlational research (penelitian korelasional) dengan desain explanatory (penjelasan), karena penelitian ini ingin mengetahui sejauhmana hubungan variabel sikap terhadap beban tugas dengan stres akademik mahasiswa fakultas kedokteran. Penelitian ini dilakukan dengan metode kuisioner.

Pada penelitian ini peneliti memilih menggunakan rancangan cross sectional sehingga variabel bebas (faktor risiko) dan variabel tergantung (efek) diobservasi hanya sekali pada saat yang sama ${ }^{9}$. Populasi merupakan seluruh objek penelitian ${ }^{9}$. Populasi dalam penelitian ini adalah mahasiswa fakultas kedokteran UMP angkatan 2014, 2016, 2017. Teknik pengambilan sampel dalam penelitian ini menggunakan probability sampling dengan jenis simple random sampling, yaitu pengambilan anggota sampel dari populasi dilakukan secara acak tanpa memperhatikan strata yang ada dalam populasi tersebut. Cara demikian dilakukan bila anggota populasi dianggap homogen ${ }^{10}$. Hal ini dilakukan karena anggota populasi yakni mahasiswa fakultas kedokteran UMP memiliki peluang yang sama untuk dipilih menjadi sampel, karena mahasiswa tersebut belajar di fakultas kedokteran dan sama-sama belajar mengenai ilmu kedokteran di fakultas kedokteran UMP pada waktu yang sama dan 
dipastikan memiliki beban tugas akademik yang sama, sehingga peneliti menentukan sampel sebanyak 149 mahasiswa yang dianggap merupakan sampel yang representatif (dapat mewakili) anggota populasi.

Setelah mengambil sampel, kemudian peneliti menganalisis data dengan menggunakan uji hipotesis dari product moment pearson dengan angka signifikansi $\mathrm{p}<0.05$, dengan syarat uji korelasi (uji parametrik) data berdistribusi normal. Untuk mengetahui normal tidaknya suatu data maka uji menggunakan uji kolmogorov smirnov dengan kriteria normal $\mathrm{p}>0.05$, jika sampel $>50^{11}$.

\section{HASIL DAN PEMBAHASAN}

Hasil penelitian dapat dilihat berikut ini:

Tabel 1. Karakteristik Data Skor Stres Akademik dan Sikap terhadap Beban Tugas

\begin{tabular}{llll}
\hline Data & Min. & Maks. & Rerata \\
\hline Skor Stres Akademik & 34 & 60 & 45.61 \\
$\begin{array}{l}\text { Skor sikap terhadap } \\
\text { beban tugas }\end{array}$ & 25 & 56 & 43.39 \\
\hline Sumber: (data primer, 2018) & & & \\
\hline
\end{tabular}

Dari Tabel 1. Diatas menunjkkan hasil penelitian berupa nilai minimum, maksimum, dan rata-rata dari skor stres akademik dan sikap terhadap beban tugas. Data skor stres akademik didapat dari hasil pengisian kuesioner Stres Akademik. Sementara itu, data skor sikap terhadap beban tugas didapat dari hasil pengisian kuesioner Sikap Terhadap Beban Tugas. Rata-rata skor stres akademik responden sebesar 45.61 dengan nilai terendah 34 dan nilai tertinggi 60. Rata-rata skor sikap terhadap beban tugas adalah 43.39 dengan nilai terendah 25 dan tertinggi 56.

Tabel 2. Hasil Uji Normalitas Data terhadap Skor Stres Akademik dan Sikap terhadap Beban Tugas dengan Uji Kolmogorov Smirnov.

One-Sample Kolmogorov-Smirnov Test

\begin{tabular}{llr}
\hline & & $\begin{array}{r}\text { Unstandardize } \\
\text { d Residual }\end{array}$ \\
\hline $\mathrm{N}$ & Mean & 149 \\
Normal Parameters ${ }^{\mathrm{a}, \mathrm{b}}$ & $\begin{array}{l}\text { Std. } \\
\text { Deviation }\end{array}$ & 3.40000000 \\
& Absolute & .059 \\
Most Extreme & Positive & .059 \\
Differences & Negative & -.049 \\
Kolmogorov-Smirnov Z & & .719 \\
Asymp. Sig. (2-tailed) & .679 \\
\hline $\begin{array}{l}\text { Sumber: (data primer, 2018) } \\
\text { a. Test distribution is Normal. } \\
\text { b. Calculated from data. }\end{array}$ & \\
\hline
\end{tabular}

Berasarkan data di atas, diketahui bahwa nilai signifikansi sebesar 0.679 lebih besar dari 0.05, sehingga dapat disimpulkan bahwa data berdistribusi normal.

Tabel 3. Hasil Uji Korelasi Pearson Stres Akademik dengan Sikap terhadap Beban Tugas

\begin{tabular}{lll}
\hline & \multicolumn{2}{l}{ Stres Akademik } \\
\hline $\begin{array}{l}\text { Sikap terhadap beban } \\
\text { tugas }\end{array}$ & $\mathrm{p}$ & 0.000 \\
& $\mathrm{r}$ & 0.626 \\
& $\mathrm{n}$ & 149 \\
\hline \multicolumn{2}{l}{ Sumber: (data primer, 2018) }
\end{tabular}

Dari Tabel. 3 diatas menunjukkan bahwa uji korelasi Pearson terhadap variabel Stres akademik dan sikap terhadap beban tugas mendapatkan nilai probabilitas (p) sebesar 0.000 dan nilai koefisien korelasi (r) sebesar 0.626. Nilai probabilitas (p) yang didapatkan kurang dari 0.05 , yaitu sebesar 0.000 , menunjukkan adanya hubungan yang signifikan antara stres akademik dengan sikap terhadap beban tugas pada 
mahasiswa Kedokteran Universitas Muhammadiyah

Purwokerto. Nilai koefisien korelasi sebesar 0.626 menunjukkan adanya kekuatan hubungan yang kuat antara stres akademik dengan sikap terhadap beban tugas. Nilai koefisien korelasi tersebut juga menunjukkan arah hubungan yang positif antara stres akademik dengan sikap terhadap beban tugas.

Berdasarkan hasil analisis data penelitian dengan menggunakan uji korelasi pearson menunjukkan hubungan antara stres akademik dengan sikap terhadap beban tugas mahasiswa fakultas kedokteran $(\mathrm{p}=0.000)$, sehingga hipotesis penelitian yang diajukan diterima. Selain itu, hasil uji korelasi tersebut menunjukkan arah hubungan positif yang kuat antara stres akademik dengan sikap terhadap beban tugas $(r=0.626)$. Sehingga dapat dikatakan semakin tinggi skor variabel stres akademik, maka skor variabel sikap terhadap beban tugas juga semakin positif. Terkait dengan hasil tersebut sesuai dengan pendapat dari Govarest \& Gregoire yang menyatakan bahwa mereka yang dirinya memiliki sumber daya yang kurang memadai untuk menangani tuntutan akademik, sehingga membuat mereka mengalami stres akademik $^{12}$. Diperkuat dengan pendapat dari Siswanto (2007) yang menyatakan bahwa tanggapan individu turut memengaruhi bahwa suatu sumber stres atau stresor itu dapat menyebabkan stres atau tidak. Stresor yang sama bisa berakibat berbeda pada individu yang berbeda karena adanya perbedaan tanggapan antar individu. Sikap positif mahasiswa terhadap beban tugasnya berarti bahwa mahasiswa tersebut memandang tugas akademik sebagai sesuatu yang positif baginya karena mampu mengasah kemampuannya, dan secara emosional menjadi senang berhadapan dengan beban tugas meskipun stres akademiknya ikut meningkat.

Dalam penelitian ini dinyatakan bahwa stres akademik yang tinggi pada mahasiswa fakultas kedokteran ditanggapi secara positif (eustress), sehingga sikap terhadap beban tugasnya pun positif. Stres akademiknya ditanggapi sebagai sebuah motivasi sehingga memacu penyelesaian beban tugas dan memandang beban tugas akademik sangat berguna untuk kehidupan yang akan datang ketika memasuki dunia kerja. Namun akan berbeda halnya, jika mahasiswa mengerjakan tugas dan tidak menemukan kemampuan yang dibutuhkan maka dapat menyebabkan stres. Hal ini dapat saja terjadi karena mereka merasa tidak mampu mengerjakan tugas dengan baik $^{13}$, tuntutan tugas akademik yang tinggi, perhatian yang singkat dalam belajar, penurunan jumlah waktu belajar ${ }^{14}$, terlalu banyak materi harus dipelajari, kesulitan dalam memahami materi, terlalu banyak tugas, jadwal terlalu padat ${ }^{15}$, akibatnya terjadi sikap negatif, kehilangan minat, masalah dengan konsentrasi dan bersikap menghindari masalah ${ }^{16}$. 


\section{SIMPULAN}

Berdasarkan penelitian tersebut dapat disimpulkan bahwa terdapat hubungan yang positif antara stres akademik dengan sikap terhadap beban tugas. Semakin tinggi tingkat stres akademik, maka akan semakin postif sikap terhadap beban tugas.

\section{SARAN}

1. Bagi Mahasiswa

Berdasarkan hasil penelitian menunjukkan bahwa mahasiswa memiliki stres akademik yang tinggi dan sikap terhadap beban tugas baik. Berdasarkan hasil tersebut maka sebaiknya mahasiswa mampu memanajemen waktu secara maksimal, sabar dalam menyelesaikan tugas, dengan lebih tekun, dengan kekuatan, keyakinan, kemauan, dan selalu menjaga baik sangka terhadap proses pembelajaran, akan membuat proses studi yang dijalani menjadi lebih layak.

2. Bagi Dosen

Hasil penelitian ini menunjukkan bahwa kecenderungan stres akademik pada mahasiswa fakultas kedokteran adalah tinggi, sehingga peran serta dosen harus lebih aktif tidak hanya di ranah akademis saja, tapi juga perlu adanya pendekatan psikologis, dimana dosen harus bersedia menjadi tempat sharing atau diskusi bagi mahasiswa untuk mengemukakan pendapatnya perihal kesulitan yang dialami selama proses pembelajaran guna meminimalisir kecenderungan stres akademik yang tinggi sehingga bisa memacu prestasi mahasiswa.

\section{Bagi Fakultas Kedokteran}

Adanya data penelitian ini diharapkan fakultas kedokteran lebih memperhatikan kesejahteraan psikologis mahasiswanya, dan membimbing mahasiswa dengan bimbingan yang dapat membantu mahasiswa dalam menyesuaikan din' terhadap beb an studi, memberikan layanan konsultasi pada mahasiswa, guna untuk mengemukakan pendapat mengenai kesulitan yang dialami selama menempuh studi, dan sebaiknya diadakan pelatihan manajemen stres yang diselenggarakan untuk mahasiswa.

4. Bagi Peneliti Selanjutnya

Bagi peneliti lain dapat meneliti faktor-faktor lain yang memengaruhi stres akademik mahasiswa sehingga perlu tambahan banyak variabel yang dapat digunakan dalam menjelaskan sikap terhadap beban tugas mahasiswa yang lebih komplek. Penelitian selanjutnya perlu subjek yang lebih banyak dengan demografi yang berbeda, persepsi mahasiswa tentang beban tugas dan perbedaan status ekonomi, suku, budaya mahasiswa. 


\section{DAFTAR PUSTAKA}

1. Salam, H.B. 2004. Cara Belajar yang Sukses di Perguruan Tinggi. Jakarta: PT. Rineka Cipta

2. Rumiani. 2006. Prokrastinasi Akademik Ditinjau dari Motivasi Berprestasi dan Stres Mahasiswa. Jurnal Psikologi UNDIP. Vol.3, No.2 (37-48).

3. Siswanto. 2007. Kesehatan Mental. Konsep, Cakupan dan Perkembangannya. Yogyakarta: Andi Offset

4. Taylor, S.E., Peplau, L.A., dan Sears, D.O. 2009. Psikologi Sosial. Edisi Kedua Belas. Alih Bahasa: Tri Wibowo, B.S. Jakarta: Kencana Prenada Media Group.

5. Goliszek, A. 2005. Manajemen Stres. Jakarta: PT Buana Ilmu Populer.

6. Diahsari, E.Y. 2001. Kontribusi Stres pada Produktivitas Kerja. Anima. Vol.16, No.4 (360371).

7. Walgito, B. 2003. Psikologi Sosial Suatu Pengantar. Yogyakarta: Andi Offset.

8. Azwar, S. 2013. Sikap Manusia : Teori dan Pengukurannya. Yogyakarta: Pustaka Pelajar.

9. Susila \& Suyanto. 2015. Metodologi Penelitian Cross Sectional Kedokteran \& Kesehatan. Klaten: Penerbit BOSSSCRIPT.

10. Sugiyono. 2011. Metode penelitian kuantitatif, kualitatif dan R \& D. Bandung: Alfabeta.

11. Dahlan, S. 2014. Statistik untuk kedokteran dan kesehatan. Jakarta: Epidemiologi Indonesia.

12. Govarest, S \& Gregoire, J. 2004. Stressfull academic situations: study on appraisal variabels in adolesence. British journal of clinical psychology, 54, 261-271

13. Odaci, H. 2012. University students ways of coping with stress, life satisfaction and subjective well-being. The online journal of counseling and education, 1(3),118-131

14. Coccia, C., Darling, C.A., Rehm, M., Cui, M. \& Sathe, S.K. 2011. Adolescent health, stress and life satisfaction: the paradox of indulgent parenting. Stress and health. Publikasi online. Doi: 10.1002/smi.1426

15. Gunawati, R., Hartati, S., dan Listiara, A. 2006. Hubungan antara Efektifitas Komunikasi Mahasiswa-Dosen Pembimbing Utama Skripsi dengan Stres dalam Menyusun Skripsi pada Mahasiswa Program Studi Psikologi Fakultas Kedokteran Universitas Diponegoro. Jurnal Psikologi UNDIP. Vol.3, No.2 (93-99).

16. Yusoff, M.S.B. 2010. Stress, stressors and coping strategies among secondary school students in a malaysian government secondary school: initial findings. Journal of psychiatry, 11(2), 1-15

17. Veresova, M. 2013. Procrastination, stress and coping among primary school teachers. Procedia social and behavior sciences, 106,2131-2138. Doi:10.1016/j.sbspro.2013.12.243 